IJOTL TL, Vol. 5, No. 1, January 2020

p ISSN: 2502 2326; e ISSN: 2502 8278

Https://soloclcs.org; Email: ijolt1@gmail.com

Center of Language and Cultural Studies, Surakarta, Indonesia

Susanto \& Hidayati, Meiliana. 2020. The Effect of Peer Review on Students'

Motivation and Writing Ability.

IJOTL TL (2020), 5(1): 1 14. DOI: 10.30957/ijot1 tl.v5i1.611.

\title{
The Effect of Peer Review on Students' Motivation and Writing Ability
}

\author{
Susanto $^{1}$ \& Meiliana Hidayati ${ }^{1}$ \\ State Islammic Institute (IAIN) of Tulungagung, Indonesia \\ Email: damarsusanto53@yahoo.co.id \& \\ meiliana.hidayati90@gmail.com
}

\begin{abstract}
The objective of this research was aimed to investigate the effect of peer review on students' motivation and ability in writing recount text. The method of the research was quasi-experimental design with control and experimental group and post-test only. The population of this research was the entire eight grade students of SMPN 1 Tanggunggunung. The cluster random sampling was used in the sampling technique. There were two classes of eight grade students as the sample of this research. They were VIII D that consists of 32 students as the control class and VIII G that consists of 30 students as the experimental class. Test and questionnaire were the instruments of this research. The data collected from the tests were analyzed by using independent sample $t$ test and MANOVA through SPSS. Results show that the independent sample t-test was 0.001 for motivation and 0.000 for the writing ability. Moreover, the result of MANOVA test was 0.000 . The results were consulted to the score of the significant value generated Sig. $\left(\mathrm{P}_{\text {value }}\right)<\alpha=0.05$. Thus, $\mathrm{H}_{\mathrm{o}}$ was rejected and $\mathrm{H}_{\mathrm{a}}$ was accepted. In other words, the result of the study revealed that peer review gave significant effect to the students' motivation and ability in writing recount text. It can be concluded that there is a significant effect to the students' writing motivation and writing ability who taught using peer review.
\end{abstract}

Keywords: per review, essay, writing motivation.

\section{INTRODUCTION}

Related to English subject as one of important components in the spectrum of the 2013 curriculum applied in Junior High School, it has a goal to develop the ability of students to communicate in that language. In this curriculum, students of junior high school are expected to be able to listen, speak, read, and write English in daily communication. Writing is taught in every level of junior high school. There are many types of writing texts that must be taught by the teacher such as narrative, descriptive, recount, report, and procedure. In this research recount text was used to develop 
IJOTL TL, Vol. 5, No. 1, January 2020

p ISSN: 2502 2326; e ISSN: 2502 8278

Https://soloclcs.org; Email: ijolt1@gmail.com

Center of Language and Cultural Studies, Surakarta, Indonesia

Susanto \& Hidayati, Meiliana. 2020. The Effect of Peer Review on Students'

Motivation and Writing Ability.

IJOTL TL (2020), 5(1): 1 14. DOI: 10.30957/ijotl t1.v5i1.611.

students' writing ability. This is based on the standard competence in point 3.11 and 4.11 (Permendikbud No.24, 2016).

Elbow (1973) said that writing a two-step process. The first is figuring out the meaning and the second is putting the meaning into language. It means that writing is a productive process done through some stages. Firstly, exploring and transmitting ideas, thought and feeling into written form. Secondly, conducting a number of revising process to carry out a grammatically and orderly texts. The writing productions are in the forms of readable texts which should be meaningful to everyone who read the writing.

Furthermore, it can be stated that writing skill is a complex activity in producing a qualified writing. The complex activity consists of stages as the steps in writing. To improve students' writing skill, the teaching and learning process of writing needs to be done well with developed input and effective activities. As a result, teachers need to consider the teaching of writing skill well based on their student's needs, ability and capacity.

According to Ellis (1996), motivations are shaped by the teacher's initiative and the students will do succeed. Le (2000) also shares the view L2 learners are bound to extrinsic motivation as a result of the pressure to pass exams. Moreover, as a matter of fact, many students tend to be more interested in learning other skills such as speaking, reading and listening than writing, and writing. Moreover, motivation is one of important aspects in writing. Without a strong motivation, students will be difficult to do writing activity. Theoretically, motivation is all of inner power reinforcing any person to do something. So, writing motivation is an inner power that determines successful writing activity. The students need motivation in writing, because with motivation they will active to do writing activity. Even though, they will find many problems such as structure grammar, diction, spelling, vocabulary and punctuation, having strong motivation will help the students to make a good composition. It proves that motivation needed by students in writing.

Knowing that the students should have the strong motivation to learn writing English, the role of English teacher instructor is very crucial. The teacher should have appropriate strategy in his/her classroom to build up the students' writing motivation. As we know, there are many strategies in teaching writing English, one of them is peer review. Peer review (a term that is used interchangeably with peer response, peer feedback and peer evaluation) has become a common practice in many L2 and FL classrooms.

Ferris (2014) stated that Peer review is in part due to the widespread influence of process oriented writing instruction, which encourages the production of multiple drafts of writing with response and revision. Feedback can motivate and improve learning, so it is essential for students to be provided with effective, timely and appropriately (Pearce, 2009). Feedback that focuses on growth rather than grading tends to make sense to students and is far more likely to advance student learning than feedback that does not make sense to students (Ferris, 2004). Students are more motivated to engage with and use feedback when the immediate utility of that feedback 
IJOTL TL, Vol. 5, No. 1, January 2020

p ISSN: 2502 2326; e ISSN: 2502 8278

Https://soloclcs.org; Email: ijolt1@gmail.com

Center of Language and Cultural Studies, Surakarta, Indonesia

Susanto \& Hidayati, Meiliana. 2020. The Effect of Peer Review on Students'

Motivation and Writing Ability.

IJOTL TL (2020), 5(1): 1 14. DOI: 10.30957/ijot1 t1.v5i1.611.

is clear. They want feedback to be something that helps them do better in the next task or, when feedback is given on drafts, something that can immediately be used to improve the final product (Min, 2006).

Fundamental issues relating to peer review, such as how to train students, how to form groups, the types of activities to conduct, and the methods to be used are all dependent on the unique needs of the students involved (Rollinson, 2005). Many studies, however, support the idea that peer review can be extremely effective for a variety of reasons when they are used correctly, especially when students are trained on how to give and use feedback (Min, 2006). Teachers can incorporate it as a way to present writing skills to students, ideally creating a student-centered classroom with learners capable of critically evaluating their own written work (Braine, 2003).

Peer review for L2 learners also provides students with the opportunity to use language in the classroom in a meaningful way (Krashen, 1982), thus improving not only their writing but also allowing them to practice their listening and speaking abilities (Tang \& Tithecott, 1999). Peer review sessions can teach students important writing skills, such as writing to a real audience, seeing ideas and points of view other than their own, and discussing how to revise writing effectively (Lee, 1997). Finally, peer review teaches students how to work in groups with their peers. Peers revise the essays and make improvements. The teachers' role here is just to facilitate where they need to guide the students and help out with difficult words and so on.

One of the most influential paradigms in approaches to motivation is proposed by the self-determination theory (Dorney, 2012). This theory distinguishes between intrinsic motivation, which refers to motivation to engage in an activity for the sake of enjoying pleasure and satisfaction in doing it, and extrinsic motivation, which is related to activity engaged to achieve an instrumental end such as getting an extrinsic reward or avoiding a punishment.

For most students, early adolescence is a time of change and transition. With respect to interpersonal relationships and social adjustment, these changes reflect a growing psychological and emotional independence from adults and a corresponding dependence on peer relationships to establish and maintain positive perceptions of the self (Steinberg, 1990). Often confounding these general developmental challenges is a transition to a new school environment, which tends to be marked by adolescents' perceptions that teachers no longer care about them, and decreased opportunities to establish meaningful relationships with peers (Eccles \& Medley, 1989). Therefore, young adolescents often must negotiate and establish relationships with adults and peers under less than optimal conditions.

Many researchers discussed about the peer review in increasing students' motivation or the correlation between motivation and writing ability, however not many of them investigate more about the effect of peer review in students' motivation and writing ability in the level of junior high school. Most of them used university students as their subject who has high level in English mastery. Students of Junior high school have learnt English when they were at Elementary school, so it is important to realize 
IJOTL TL, Vol. 5, No. 1, January 2020

p ISSN: 2502 2326; e ISSN: 2502 8278

Https://soloclcs.org; Email: ijolt1@gmail.com

Center of Language and Cultural Studies, Surakarta, Indonesia

Susanto \& Hidayati, Meiliana. 2020. The Effect of Peer Review on Students'

Motivation and Writing Ability.

IJOTL TL (2020), 5(1): 1 14. DOI: 10.30957/ijot1 tl.v5i1.611.

that they are able to give some revision or editing to their peers and those ways make them feel comfortable and enjoy the learning process.

Having peer relationships is to establish and maintain positive perceptions of the self (Steinberg, 1990). Feedback can motivate and improve learning, so it is essential for students to be provided with effective, timely and appropriate feedback (Pearce, Mulder \& Baik, 2009). Feedback that focuses on

"growth rather than grading" (Sadler, 1983) tends to make sense to students and is far more likely to advance student learning than feedback that does not make sense to students (Gibbs \& Simpson, 2004).

Therefore, this study was conducted to know whether peer review technique is able to effect the students' motivation by treating writing as a collaborative social activity and their performance in writing personal recount text. Peer review can be a way to open up new possibilities for both writer and reviewer. A final issue examined in this study concerns the role of peer review as the strategy in explaining the effect between motivation and academic achievement. Having supportive relationships with parents, teachers, and peers has been associated with academic success (Wentzel \& Asher, 1995). On the one hand, supportive relationships might be related directly to academic achievement independent of their relations to motivational outcomes.

\section{RELATED REVIEW LITERATURE}

Teaching English at Junior high school is based on the school based curriculum. There are some kinds of curriculum that implemented in school of Indonesia, and the current curriculum is 2013 curriculum that used almost in school levels. The 2013 curriculum of English subject also has a similar basic with the basic competency of curriculum (curriculum before KTSP) which aims to be able to have communication both orally and written in English.

Communication means understanding and expressing thought, feeling, information, and developing knowledge, technology and culture. Competence for communication in the whole meaning is competence discourse that is competence to understand and produce some oral and written text. They are stated in four language skills namely, listening, speaking, reading, and writing. In junior high school, all of the skills have standard competencies (Permendiknas, 2013). They are listening, speaking, reading and writing.

In teaching writing, there are some main and basic competencies that have to be reached by junior high school students, one of the main competencies that included recount text is taught in eight grade students. This main competency is comparing the social function, text structure, and language feature in personal recount text both written and orally by giving and asking the information that deal with personal experience in the past (Permendiknas, 2013).

Definition of writing is conveyed differently by some experts. They are; (a) Harmer (2007) states that writing is the representation of language in a textual medium 
IJOTL TL, Vol. 5, No. 1, January 2020

p ISSN: 2502 2326; e ISSN: 2502 8278

Https://soloclcs.org; Email: ijolt1@gmail.com

Center of Language and Cultural Studies, Surakarta, Indonesia

Susanto \& Hidayati, Meiliana. 2020. The Effect of Peer Review on Students'

Motivation and Writing Ability.

IJOTL TL (2020), 5(1): 1 14. DOI: 10.30957/ijot1 f1.v5i1.611.

through the use of a set of sign or symbols (known as a writing system); (b) says that writing is various stages (planning, drafting, editing, etc.) that writers go through in a variety of sequences in order to compose written text. (c) Writing is considered a problem-solving process in which writers attempt to produce visible, legible, and understandable language reflecting knowledge of their topic or thoughts and feelings. Graham (1982) states that writing is making their meaning that known to others and the endgame is conveying ideas and emotions to someone else, most likely an absent other.

Writing ability often is a criterion dependent variable in many studies of writing motivation. Pajares and Valiante (1999) found that self-efficacy beliefs and prior writing achievement (using English/language arts grades) were the only significant predictors of teachers' ratings of students' writing competence; writing apprehension, self-concept, perceived task value, and self-efficacy for self regulation did not contribute significantly to the prediction of writing competence. According to Bandura (1997), when prior achievement in writing is used as a predictor of current writing performance, the prior impact of motivational determinants of writing performance also are captured by the measure of prior writing achievement. This is an important consideration when examining factors that influence writing motivation and performance.

There are many types of English text that taught in the level of junior high school such as descriptive, narrative, procedure and recount. It can be concluded that there are many kinds of text that must be mastered by the students in writing for increasing the students' writing ability. A recount is a piece of text that retells past events, usually in the order in what they occurred. Its purpose is to provide the audience with a description of what occurred and when it occurred (Graham, 1982). Recount texts include experience, eyewitness, newspaper reports, letter, television interviews and speeches.

Testing is important for almost all the people involved in the education process. Language testing has long been an important area in applied linguistics, partly because construct such as language proficiency has to made explicit if they are serve as models for testing design and validation purposes (Allison, 1990).

The learners want to know how well he is doing and want 'the piece of' at the end of the course that will help open professional doors. The teacher wants to know not only how the learners is progressing but also how he, the teacher, is succeeding in his job (Harmer, 2007).

Motivation is defined as the process whereby goal-directed activities are instigated and sustained (Schunk, 2014). Motivation is a drive that influences how we learn. Students who believe they can complete a skill or task is often more motivated to see it through. And, visa versa, students who feel they cannot complete a skill or task often lack motivation to persevere. For example, a student who does not value writing and views the tasks as just another assignment may not be motivated to finish the task or do his/her best work. The student may also avoid the task all together. 
IJOTL TL, Vol. 5, No. 1, January 2020

p ISSN: 2502 2326; e ISSN: 2502 8278

Https://soloclcs.org; Email: ijolt1@gmail.com

Center of Language and Cultural Studies, Surakarta, Indonesia

Susanto \& Hidayati, Meiliana. 2020. The Effect of Peer Review on Students'

Motivation and Writing Ability.

IJOTL TL (2020), 5(1): 1 14. DOI: 10.30957/ijot1 t1.v5i1.611.

Moreover, motivation is what keeps students going when faced with challenging or, sometimes, unattractive work. This is especially important for writing instruction, as students are often faced with complex tasks. Schunk and colleagues (2014) noted that motivation might differ across subject areas and tasks. In fact, a student may be highly motivated to learn new skills related to science, but be unmotivated when learning new writing skills. Motivation, which is domain-specific, also changes as students advance through the grade levels (Troia, 2009).

Additionally, Gardner's motivation theory has been profoundly influential in the L2 motivation field for decades. According to Gardner (2001), motivation includes three elements effort (the effort to learn the language), desire (wanting to achieve a goal) and positive affect (enjoy the task of learning the language). The role of orientations, which Gardner refers to as a "goal" aims to arouse motivation and direct it to reach the goals. Two orientations in particular integrative orientation and instrumental orientation were introduced by Gardner and his associates and have been discussed and explored in L2 motivation research extensively.

According to Gardner (2001), integrative orientation refers to a positive attitude towards the L2 community and the desire to get close to the community and even become a member of that community. As a counterpart to integrative orientation, instrumental orientation is defined as learning an L2 for pragmatic reasons, such as getting a better job or a higher salary. There are three main influences of motivation including expectancy, incentive, and motive (Atkinson, 1957).

Self-efficacy, an individual's assessment of his or her competence to perform a future task, is perhaps the most well established and well researched aspect of human motivation (Bandura, 1997). He also said that self-efficacy beliefs comprise both outcome expectations, which are beliefs that particular actions will lead to desired outcomes, and efficacy expectations, which are beliefs that one is capable of performing those actions to achieve goals. For instance, one might believe an action will yield a particular result revising a report several times for clarity and detail will produce a more polished and informative paper but not necessarily that one can successfully perform the requisite action.

In conjunction with self-efficacy beliefs, task interest and value influence the selection of goals and represent another core component of human motivation within expectancy-value theory (e.g., Hidi, Berndorff, \& Ainley, 2002). Interest reflects, in part, the personal significance or value attached to a task (Wigfield \& Eccles, 1992; Schiefele, 1999). Individuals with strong personal interest in a topic or activity will pay greater attention, persist longer, enjoy their involvement, and acquire more knowledge than those lacking interest (e.g., Schiefele, 1991).

Peer reviewing is referred to as 'peer feedback", which is an assessment form performed by equal status learners (Hyland, 2003). In peer review a student does more than simply editing and evaluating another student's essay. Students respond to what the essay says as well as how it says it (Mangelsdorf, 1992). Peer reviewing is a powerful learning tool which provides students with an authentic audience; increases their 
IJOTL TL, Vol. 5, No. 1, January 2020

p ISSN: 2502 2326; e ISSN: 2502 8278

Https://soloclcs.org; Email: ijolt1@gmail.com

Center of Language and Cultural Studies, Surakarta, Indonesia

Susanto \& Hidayati, Meiliana. 2020. The Effect of Peer Review on Students'

Motivation and Writing Ability.

IJOTL TL (2020), 5(1): 1 14. DOI: 10.30957/ijot1 tl.v5i1.611.

motivation to write; enables them to receive different views on their writing and read their own writing critically; and assists them in gaining confidence in their writing (Mittan, 1989).

For the purpose of this study, peer reviewing is meant to refer to the process where L2 writing students collaborate to assess one another's written composition, which, in this study, refers to essay writing as a replacement of teacher based feedback in L2 writing sessions. However, there are still some drawbacks for peer review. What comes from students are not necessarily correct and precise. Moreover, students criticize their enemies, and they praise their friends and thus in effect tend to be bias.

Lam (2010) stated that students have difficulty in making sincere and truthful judgments. Lam (2010) also mentioned that peers feel prejudiced emotionally against giving low grades to their classmates. They tend to help their friends by giving high marks. There are different levels of students and their responses may vary. During peer evaluation, students are said to overestimate and underestimate their peers. This was supported by Caulk (2002) who stated that peers tend to underestimate and overestimate their friends. Low achievers tend to overestimate high achievers and high achievers tend to underestimate low achievers.

\section{METHODS}

\subsection{Design}

In conducting the research the writer applied the quantitative research design as the research method. Quantitative method is a method that correlates with statistical analysis of the data, which is typically in numeric form (Creswell, 2012). Afterwards, because this study examines the effect of peer review in students' motivation and writing ability, the quasi-experimental design was applied with the matching-only posttest control and experiment group designs. Essentially, the writer assigns intact groups of the experimental and control treatments, and conducts the experimental treatment activities with the experimental group only in which using peer review technique as the treatment activity, and then administers a post-test to assess the differences between two groups (Creswell, 2012).

The population of this research is the entire eighth grades in SMPN 1 Tanggunggunung. They are in academic year 2018/2019. The eighth grades students of SMPN N 1 Tanggunggunung are taken as the population since it is done the fact that in curriculum 2013 recount text is taught. The entire eighth grades students are divided into seven classes. The seven classes are class VIII A up to G. Each of class consists of $30-32$ students. The total of students at eighth grade in SMPN 1 Tanggunggunung is 220 students. 
IJOTL TL, Vol. 5, No. 1, January 2020

p ISSN: 2502 2326; e ISSN: 2502 8278

Https://soloclcs.org; Email: ijolt1@gmail.com

Center of Language and Cultural Studies, Surakarta, Indonesia

Susanto \& Hidayati, Meiliana. 2020. The Effect of Peer Review on Students'

Motivation and Writing Ability.

IJOTL TL (2020), 5(1): 1 14. DOI: 10.30957/ijot1 tl.v5i1.611.

The researcher chooses the classes that will be the control and experimental group by using clustered random sampling. Charles (1993) stated that Cluster sampling technique involves the random selection of groups that already exist. To make sure that the groups are chosen randomly, the researcher uses lottery to choose the experimental and control group. As a result, class $\mathrm{D}$ becomes the control class and class $\mathrm{G}$ becomes the experimental class.

In this study, the researcher used some instruments for gaining the data. The instruments were questionnaire and test. The first instrument was questionnaire which to know the level of students' motivation which deals with students' in learning writing English. It is covering intrinsic, extrinsic of motivation, task value, control of beliefs and self-efficacy for learning and performance that developed from Academic Writing Motivation Questionnaire (2012).

After collecting the data, the data was analyzed by using t-test and MANOVA to reveal the hypotheses. A t-test compares the means of the data sets to determine if there is a statistically significant difference (Stanley, 2015). The data sets are independent of one another and not related, therefore, this is sometimes referred to as the independent-sample t-test. In this study t-test was used to compare the test scores of students who got peer review technique with the test scores of student that do not use peer review technique. The t-test was to answer the first and second the hypotheses.

Moreover, Multivariate analysis of variance (MANOVA) is a procedure for comparinghttps://en.wikipedia.org/wiki/Multivariate random variablemultivariatehttps ://en.wikipedia.org/wiki/Multivariate random variablesample means. As a multivariate procedure, it is used when there are two or morehttps://en.wikipedia.org/wiki/Dependent_variablesdependent variableshttps://en.wikipedia.org/wiki/Dependent variables (Warne, 2014). The researcher used MANOVA to reveal the third hypothesis whether there is significant effect of peer review in students' writing motivation and students' writing ability simultaneously.

\section{RESULTS AND DISCUSSION}

Hypothetical Test of Motivation

Independent Samples Test

\begin{tabular}{|l|l|l|}
\hline $\begin{array}{l}\text { Levene's } \\
\text { Test for } \\
\text { Equality } \\
\text { of } \\
\text { Variances }\end{array}$ & t-test for Equality of Means \\
\hline
\end{tabular}




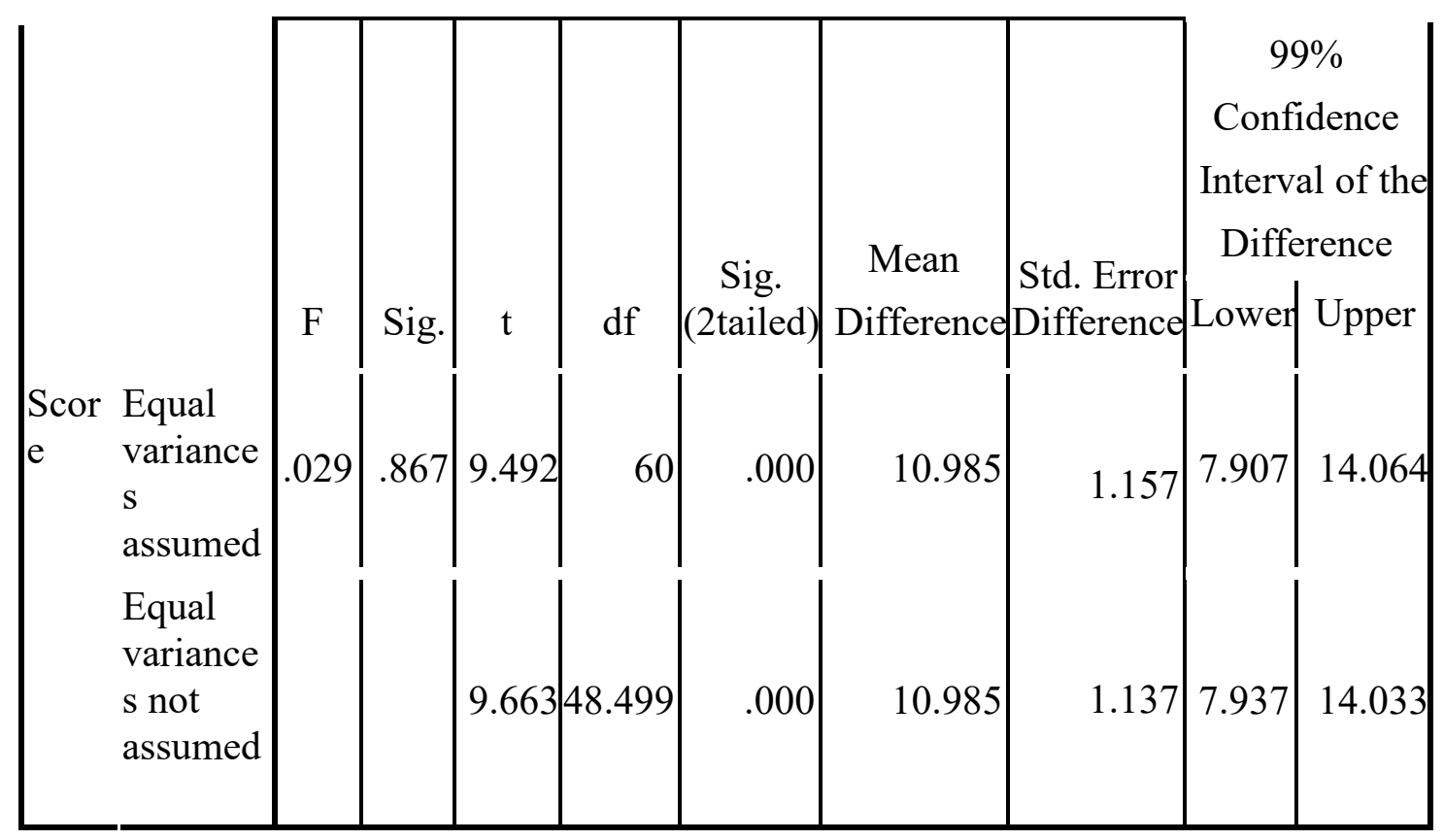

Based on the results obtained in the independent sample t-test above, that the value of significant generated $\operatorname{Sig}\left(\mathrm{P}_{\text {value }}\right)=0.000<\alpha=0.05$. So, Ho is rejected and $\mathrm{H}_{\mathrm{a}}$ is accepted. Based on the computation, it can be concluded that there was a significant effect of using Peer Review in students' writing motivation at the second semester of the eighth grade of SMPN 1 Tanggunggunung in 2018/2019 academic year.

Hypothetical Test of Writing ability

Independent Samples Test

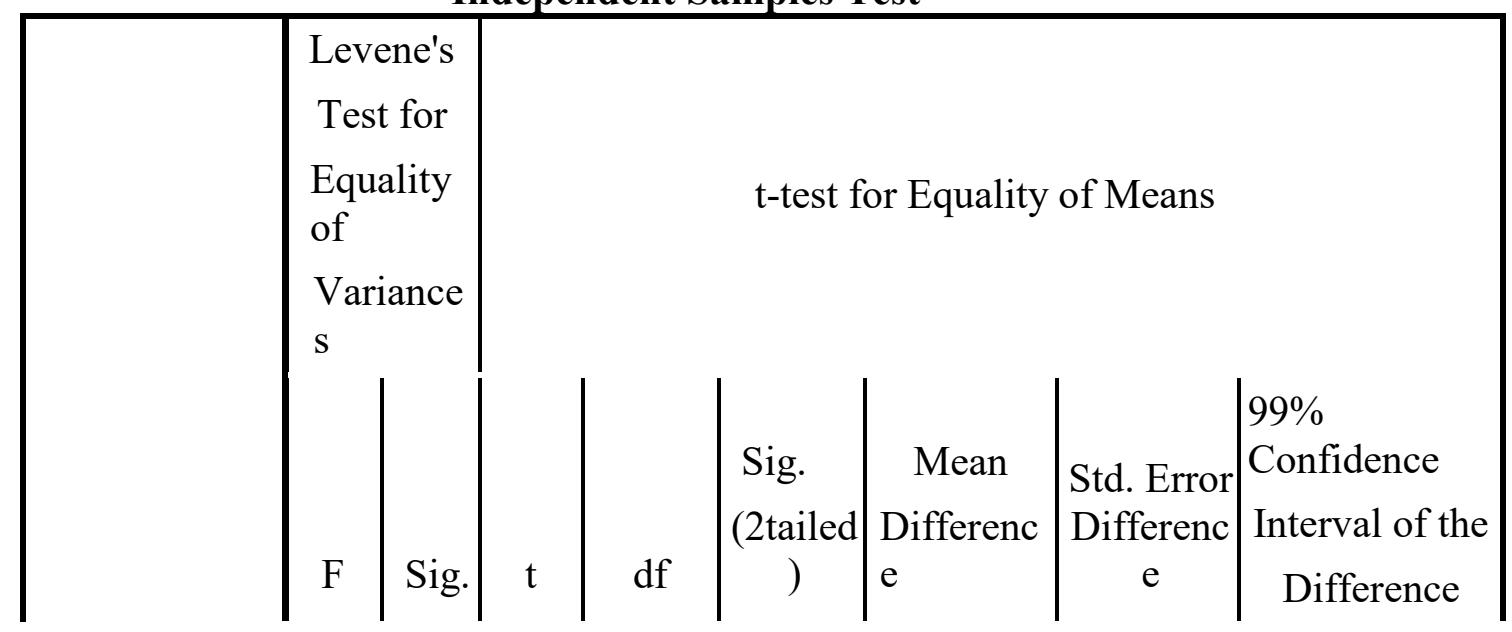




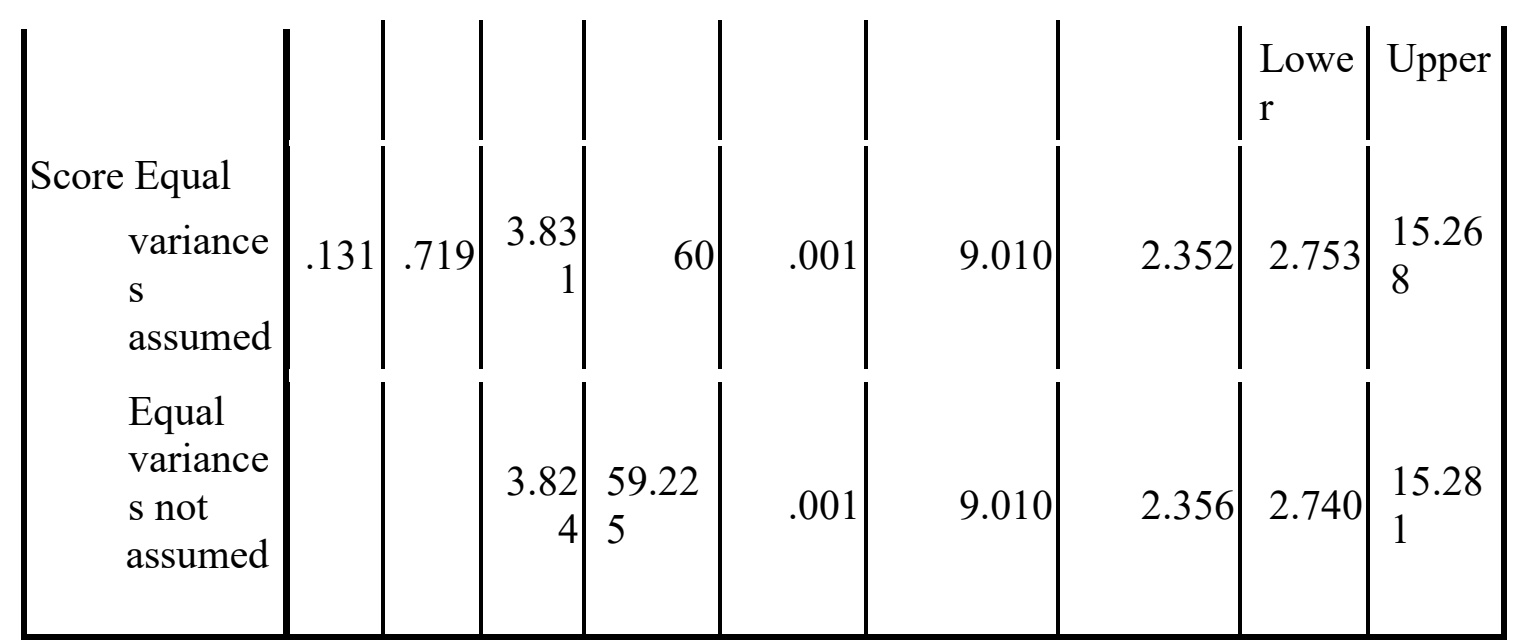

Based on the results obtained in the independent sample t-test above, that the value of significant generated $\operatorname{Sig}\left(\mathrm{P}_{\text {value }}\right)=0.001<\alpha=0.05$. So, Ho is rejected and $\mathrm{H}_{\mathrm{a}}$ is accepted. Based on the computation, it can be concluded that there was a significant effect of using Peer Review in students' writing recount text ability at the second semester of the eighth grade of SMPN 1 Tanggunggunung in 2018/2019 academic year.

Result of MANOVA Test

Multivariate Tests ${ }^{\mathrm{c}}$

\begin{tabular}{|c|c|c|c|c|c|c|c|c|}
\hline \multicolumn{2}{|l|}{ Effect } & Value & $\mathrm{F}$ & $\begin{array}{c}\text { Hypothesis } \\
\text { df }\end{array}$ & $\begin{array}{l}\text { Error } \\
\text { df }\end{array}$ & Sig. & $\begin{array}{l}\text { Noncent. } \\
\text { Parameter }\end{array}$ & $\begin{array}{c}\text { Observed } \\
\text { Power }^{\mathrm{b}}\end{array}$ \\
\hline \multicolumn{2}{|c|}{ Intercept Pillai's Trace } & .997 & $9.628 \mathrm{E} 3^{\mathrm{a}}$ & 2.000 & 59.000 & .000 & 19255.843 & 1.000 \\
\hline & $\begin{array}{l}\text { Wilks' } \\
\text { Lambda }\end{array}$ & .003 & $9.628 \mathrm{E}^{\mathrm{a}}$ & 2.000 & 59.000 & .000 & 19255.843 & 1.000 \\
\hline & $\begin{array}{l}\text { Hotelling's } \\
\text { Trace }\end{array}$ & 326.370 & $9.628 \mathrm{E}^{\mathrm{a}}$ & 2.000 & 59.000 & .000 & 19255.843 & 1.000 \\
\hline & Roy's Largest & & $9.628 \mathrm{E} 3^{\mathrm{a}}$ & & & & & \\
\hline & Root & 326.370 & & 2.000 & 59.000 & .000 & 19255.843 & 1.000 \\
\hline Class & Pillai's Trace & .625 & $49.258^{\mathrm{a}}$ & 2.000 & 59.000 & .000 & 98.515 & 1.000 \\
\hline
\end{tabular}


IJOTL TL, Vol. 5, No. 1, January 2020

p ISSN: 2502 2326; e ISSN: 2502 8278

Https://soloclcs.org; Email: ijolt1@gmail.com

Center of Language and Cultural Studies, Surakarta, Indonesia

Susanto \& Hidayati, Meiliana. 2020. The Effect of Peer Review on Students'

Motivation and Writing Ability.

IJOTL TL (2020), 5(1): 1 14. DOI: 10.30957/ijotl tl.v5i1.611.

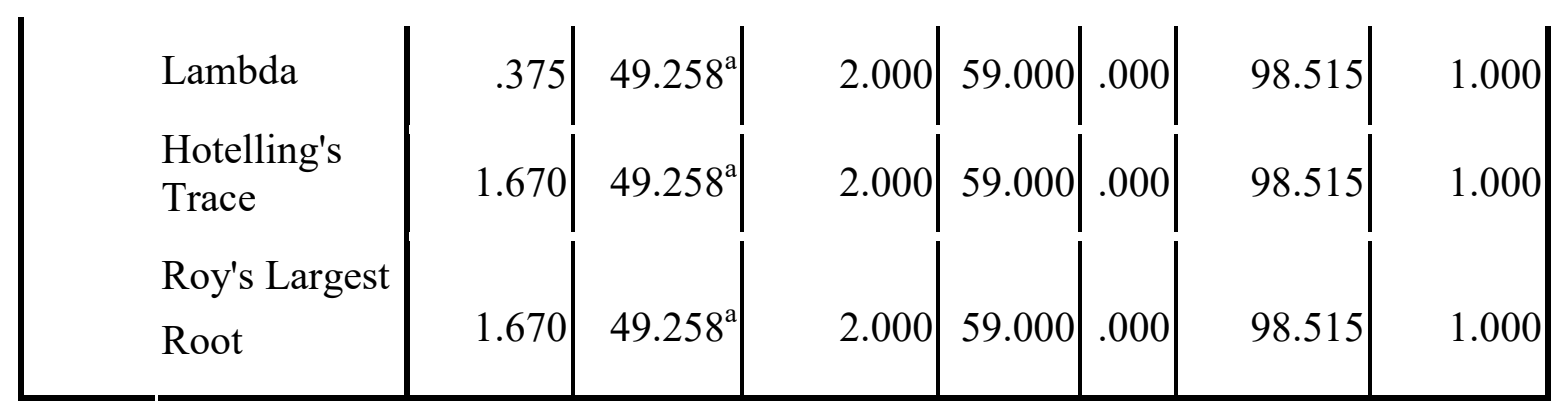

a. Exact statistic

b. Computed using alpha $=.05$

c. Design: Intercept + Class

Based on the table above, the significant value of $\mathrm{F}$ class test of Pillai's Trace, Wilk's Lambda, Hotelling's trace and Roy's Larget Root showed 0.000. It was less than 0.05 . All of the significance values were significant. Thus, the null hypothesis was rejected. It meant that, the statement which stated 'there is no significant effect of peer review on students' writing motivation and writing ability' was rejected. Henceforth, it could be concluded that there is a significant effect of peer review on students' writing motivation and writing ability.

Furthermore, to know the differences writing motivation and writing ability both experimental and control classes, the analysis result of Test of between

Subject-Effects could be used.

\section{CONCLUSION}

After conducting the research and analyzing the data, the researcher draws a conclusion based on the hypotheses as follows: 1.There is a significant effect of Peer Review on students' writing motivation, 2. There is significant effect of peer review in students' writing ability in recount text, and 3. There is a significant effect of Peer Review on students' writing motivation and writing ability. Because by seeing the result of the data calculation in the previous chapter where null hypothesis $\left(\mathrm{H}_{\mathrm{O}}\right)$ was rejected, and alternative hypothesis $\left(\mathrm{H}_{\mathrm{a}}\right)$ was accepted, it means that the researcher assumption is true that is to say, Peer Review Technique can give a significant on students' writing motivation and ability in writing recount text. It was supported by the scores achieved by that students in which they got higher scores both in questionnaire and writing test after the researcher gave the treatment by using Peer Review Technique as a technique in teaching writing.

The significant influence can be seen from Sig. (2-tailed) of the equal variance assumed in the independent sample t-test table where the Sig. (2-tailed) is 0.000 for the students' motivation and 0.001 for the writing test. Both the scores are lower than $\alpha=$ 0.05 and its mean Ho is rejected and $\mathrm{Ha}$ is accepted. Thus, the significant value of $\mathrm{F}$ class test of Pillai's Trace, Wilk's Lambda, Hotelling's trace and Roy's Larget Root 
IJOTL TL, Vol. 5, No. 1, January 2020

p ISSN: 2502 2326; e ISSN: 2502 8278

Https://soloclcs.org; Email: ijolt1@gmail.com

Center of Language and Cultural Studies, Surakarta, Indonesia

Susanto \& Hidayati, Meiliana. 2020. The Effect of Peer Review on Students'

Motivation and Writing Ability.

IJOTL TL (2020), 5(1): 1 14. DOI: 10.30957/ijot1 tl.v5i1.611.

showed 0.000 . It was less than 0.05 . All of the significance values were significant. Thus, the null hypothesis was rejected. It can be proved from the hypothetical test, where alternative hypothesis is accepted and null hypothesis is not accepted.

\section{REFERENCES}

Anderson, M. and Kathy A. (1997). Text Types in English. Australia: Macmillan Education Australia PTY LTD, 1997.

Arikunto, Suharsimi. (2006). PenelitianTindakanUntuk Guru, Sekolah, dan Dosen, Yogyakarta: RinekaCipta.

Ary, Donald. (2010). Introduction to Research in Education. 8th Edition. Canada: Wadsworth.

Atkinson, J.W.. (1957). Motivational determinants of Risk-Taking behavior, Journal of Psychological Review, 64, 359-372.

Bandura, A. (1997). Self-efficacy: The Exercise of Control. New York: Henry Holt \& Co.

Bartels, Nat. (2003). Written Peer Response in L2 Writing. Germany: English Teaching Forum.

Brown, H. Douglas. (1998). Principle of Language Learning or Teaching. San Francisco: Prentice Hall Inc.

Caulk, N., (1994). Comparing Teacher and Student Responses to Written Work, Journal of TESOL Quarterly, 28, 181-188.

Creswell, John W. (2012). Educational Research. Planning, Conducting, and Evaluating Quantitative and Qualitative Research. $4^{\text {th }}$ Edition. Boston: Pearson Education.

Dawson, Catherine. (2010). MetodePenelitianPraktis: Sebuah Paduan. Yogyakarta: Pustaka Pelajar.

Dörnyei, Zoltán. (2002). Motivation \& Motivating in the Foreign Language Classroom. Journal of Modern Language, 78, 515-523.

Elliott, A. J., (1999). Approach and Avoidance Motivation and Achievement Goals, Journal of Educational Psychologist, 34, 169-179. 
IJOTL TL, Vol. 5, No. 1, January 2020

p ISSN: 2502 2326; e ISSN: 2502 8278

Https://soloclcs.org; Email: ijolt1@gmail.com

Center of Language and Cultural Studies, Surakarta, Indonesia

Susanto \& Hidayati, Meiliana. 2020. The Effect of Peer Review on Students'

Motivation and Writing Ability.

IJOTL TL (2020), 5(1): 1 14. DOI: 10.30957/ijot1 t1.v5i1.611.

Ellis, G., (1996). How Culturally Appropriate is The Communicative Approach?, ELT Journal, 50 (3), 213-218.

Farida, Amalia. (2006). Cadence. Bandung: CCF.

Farrah, M. (2012). The Impact Of Peer Feedback On Improving The Writing Skills Among Hebron University Students. An - Najah Uni. J. Res.

Ferris, D. R. (2014). Response to Student Writing: Implications for Second Language Students. New Jersey: Lawrence Erlbaum Associates, Inc., Publishers.

Fraenkel, Jack R. and Norman E. Wallen. (2012). How to Design and Evaluate Research in Education.7th Edition. New York: McGraw-Hill.

Gardner, R.C. \& Lambert, W. E. (2011). Motivational Variables in Second Language Learning. Canadian Journal of Psychology, 1959, 13, 266.

Hansen, Liu. (2005). Guiding Principles for Effective Peer Response. Oxford University Press.

Harmer, J. (2007). How to Teach English: An Introduction to The Practice of English Language Teaching. Essex: Longman.

Harris, K.R., Graham, S., Mason, L.H., \& Friedlander, B. (1979). Powerful Writing Strategies for All Students. Baltimore, MD: Brookes Publishing Co., Inc.

Hedgecock, J.S., (2005). Taking Stock of Research and Pedagogy in L2 Writing. In E. Hinkel (Ed.), Handbook of research in second language teaching and learning. Mahwah, NJ: Lawrance Erlbaum publishers.

Hidi, S., \& Anderson, V. (1992). Situational Interest and Its Impact on Reading and Expository Writing, Journal of The role of Interest in Learning and Development 215-238.

Jacobs, G.M., Curtis, A., Braine, G. and Huang, S.Y. (1998). Feedback on Student Writing: Taking The Middle Path, Journal of Second Language Writing 7: 307-17.

Latief, Muhammad Adnan. (2016). Research Methods on Language Learning. Malang: UM Press.

Le, V, (2000). Language and Vietnamese pedagogical contexts. In J. Shaw, D. Lubelska \& M. Noullet (Eds.), Proceedings of the Fourth International Conference on Language and Development (pp. 73-80). Bangkok: Asian Institute of Technology. 
IJOTL TL, Vol. 5, No. 1, January 2020

p ISSN: 2502 2326; e ISSN: 2502 8278

Https://soloclcs.org; Email: ijolt1@gmail.com

Center of Language and Cultural Studies, Surakarta, Indonesia

Susanto \& Hidayati, Meiliana. 2020. The Effect of Peer Review on Students'

Motivation and Writing Ability.

IJOTL TL (2020), 5(1): 1 14. DOI: 10.30957/ijot1 t1.v5i1.611.

Lee, K, (2000). Augmented Reality, Journal of Education and Training, Vol 56 No. 2.

Legget, E.L and Dweck C.S. (1987). A Social Cognitive Approach to motivation and Personality, Journal of Psychological Review, No. 95, Stanford: Stanford University.

Leggett, E. L., \& Dweck, C. S. (1987). Children's effort/ability reasoning: individual differences and motivational consequences, Paper presented at the Biennial Meeting of the Society for Research in Child Development, Baltimore, MD.

Li, W., \& Lee, A. (2005). A Review of Conceptions of Ability and Related Motivational Constructs in Achievement Motivation. Journal of Quest, 56, 439-461.

Rotter. J.B. (1966). Generalized Expectancies For Internal Versus External Control of Reinforcement, Journal of Psychological Monographs: General and Applied, 80(1), 1-28.

Weigle, C. S. (2002). Assessing writing. Cambridge: Cambridge University Press.

Weiner, B. (1986). Attribution, Emotion, and Action. In R. M. Sorrentino \& E. T. Higgins (Eds.), Handbook of motivation and cognition: Foundations of social behavior (pp. 281-312). New York: Guilford Press.

Wentzel, K.R. and Asher, S.R. (1995). Academic Lives of Neglected, Rejected, Popular, and Controversial Children, Journal of Child Development, $62(1)$.

Wiersman, W., and Jurs S.G. (2009). Research Method in Education an Introduction. US: Pearson Education Inc.

Wigfield, A., \& Eccles, J.S. (2001). Development of Achievement Motivation. San Diego: CA Press. 